\title{
Mary Queen of Scots as Feminine and National Icon: Depictions in Film and Fiction
}

Marie Stuart, icône féminine et nationale : représentations littéraires et cinématographiques

Ingibjörg Ágústsdóttir

\section{(2) OpenEdition}

\section{Journals}

Electronic version

URL: https://journals.openedition.org/etudesecossaises/603

DOI: 10.4000/etudesecossaises.603

ISSN: 1969-6337

Publisher

UGA Éditions/Université Grenoble Alpes

Printed version

Date of publication: 15 April 2012

Number of pages: $75-93$

ISBN: 978-2-84310-223-3

ISSN: $1240-1439$

\section{Electronic reference}

Ingibjörg Ágústsdóttir, "Mary Queen of Scots as Feminine and National Icon: Depictions in Film and Fiction", Études écossaises [Online], 15 | 2012, Online since 15 October 2013, connection on 11 April 2023. URL: http://journals.openedition.org/etudesecossaises/603 ; DOI: https://doi.org/10.4000/ etudesecossaises.603 


\section{Mary Queen of Scots as Feminine and National Icon: Depictions in Film and Fiction}

This paper focuses on twentieth and twenty-first century fictional and filmic representations of Mary Stuart, otherwise known as Mary Queen of Scots. A historically significant character, cousin and rival to Elizabeth I, mother of James I and VI of England, who united the English and Scottish crowns in 1603, a focal point for Catholic resistance to religious reformation in Britain, Mary lived a dramatic life and her untimely end at the hands of Elizabeth's executioner has made her live on in the popular imagination, most prominently as the heroine of romantic tragedy, as pointed out by Roderick Graham (p. 440). Mary has figured in diverse works of literature and the arts since her death; in fact, her tragic life has been "inexhaustibly narrated from the sixteenth century forward" (Lewis, 1995, p. 166). Moreover, she has achieved legendary status in popular culture through her role as victim and Catholic martyr. Biographers do not agree as to the extent of her guilt in the Darnley murder, and commentators differ in their expressions of sympathy for or judgment against Mary, but the importance of her reign to British and Scottish history remains undisputed.

Mary's relationship with Scotland was and is complicated and paradoxical. Her reign there, after returning from France, was fraught with difficulties and the events that shocked her contemporaries at home and abroad (the murders of Rizzio and Darnley and Mary's subsequent marriage to Bothwell) are seen by modern historians as both a result of her own misguided actions and of the divisions and rivalry endemic among the Scottish nobility of the time. Mary's own Catholicism complicated matters further, and her forced abdication was clearly welcomed by Scottish Protestants. Mary was repudiated by the Scots and thrown on the mercy of her cousin Elizabeth, but eventually it was her religion and the threat it invoked that decided English policy towards her affairs. Consequently, because of her Catholicism, Mary can be seen as a symbol for an old form of religion that was forced to make way for the new religious order promoted by Elizabeth and her councillors. As a Scottish monarch, 
Mary can now also be read as representative of the subjugation - and even assimilation - of Scotland by England, despite her historical repudiation by the Scots; cultural and national memory is highly selective, and today we only need to visit Holyrood Palace or tourist shops on the Royal Mile in Edinburgh to see that Mary Queen of Scots clearly represents Scottishness in the national imagination. Nevertheless, this is a paradoxical kind of Scottishness, both because Mary's Catholicism allied her with Europe, in particular France and Spain, and because she was rejected by the country which now claims her as their most potent romantic icon.

In her Freudian study of Mary's s relationship to "the fiction of Britain", Lewis focuses on Mary as the rejected mother of a nation, the bad mother who is sacrificed for "the imagined coherence of the nationstate and its representative Elizabeth" (Lewis, 1998, p. 2, p. 11). She then proceeds to explore the literary and cultural significance of Mary by discussing various literary texts and works of art from Elizabethan times until the end of the Victorian era. Among these are Sophia Lee's The Recess (1783-5), a Romantic-Gothic fantasy tale of Mary's imagined twin daughters by Bothwell, Friedrich Schiller's play Maria Stuart (1800), which depicts the last days of the Scottish queen, and Sir Walter Scott's The Abbot (1820), a novel dealing with the end of Mary's rule in Scotland. As indicated above, the governing idea behind Lewis's study is that of Mary the feminine mother, and this is significant, not the least because in historical fiction there has been a marked tendency to assess Mary in relation to her cousin and rival, Queen Elizabeth I, Mary being the "feminine ideal, a woman victimized by her gender" while Elizabeth is the masculine woman "because she ... puts the public world of politics above the private world of emotions" (Wallace, 2008, p. 19). Importantly, this aspect of Mary is addressed by Dobson and Watson, who point out that Mary was perceived by eighteenth-century culture "as all woman" and laid claim to the position of "distressed heroine of sensibility, embodying the fate of Scotland" (pp. 98-9). They further argue that for the next two hundred years Mary shifted between genres: the sentimental epistolary novel, the romantic gothic, Victorian history painting and eventually the Hollywood motion picture (p. 99). At the same time, representations of Mary evolved from "heroine of sensibility to romantic guilty grande dame" (p. 100). Yet her essential womanly aspect was never lost: "In whatever mode she was displayed [...] Mary Stuart remained a remarkably durable and potent version of femininity, a femininity that a remarkable number of women, and women writers, seemed to want to occupy" (p. 100).

This article demonstrates that even in the late twentieth and early twenty-first centuries, fictional and filmic portrayals of Mary Queen of Scots keep emphasising this essentially feminine nature, albeit to a varying 
degree and with notable but not so obvious deviations. The denomination "femininity", in this context, refers to that which is emotional, sensitive, frivolous, weak, impulsive, delicate, sexually alluring, compassionate, and even submissive. ${ }^{1}$ The portrayals studied here thus tend to reflect stereotypical assumptions regarding feminine and, by extension, masculine qualities. These portrayals include novels and films from the 1960s and 1970 s, along with filmic and fictional portrayals of the twenty-first century. During this period of time little seems to have changed in popular perceptions of the tragic Queen of Scots as a feminine icon, regardless of important changes to women's rights and female self-perception brought by second-wave feminism in the intervening years.

\section{Mary in fiction}

Jean Plaidy (Eleanor Hibbert) was Britain's most popular historical novelist in the 1950s and 1960s. Her novels follow known facts and standard interpretations very closely rather than offering rewritings of her subject matter (Wallace, 2008, p. 136). Her first novel on Mary Stuart, Royal Road to Fotheringay (1964) covers the life of Mary from the age of four until she was placed in Lochleven Castle as a prisoner in 1567. This is an engaging and readable novel that shows Mary in a sympathetic light but tends to over-emphasise her emotional nature, e.g. through repetitive descriptions of Mary's outbursts of crying. Plaidy takes the interesting but not entirely convincing route of showing Mary as having a close but peculiar, almost sensual, relationship with her uncle the Cardinal of Lorraine when she is a young girl in France. This relationship, Plaidy argues, is the reason why "the passions of such a passionate woman were so long dormant" and were only fully recognised and awakened by "the virile Bothwell" (Author's Note, p. 493, p. 492). In this way, Plaidy aims to make Mary's total submission to and dependence on Bothwell - to the extent that her own honour and dignity are severely compromised-seem natural and inevitable.

Bothwell, whose portrayal here is defined by Wallace as "sketchy and unappealing" (Wallace, 2008, p. 139), is presented in no uncertain terms as fiercely ambitious, self-assured to the point of arrogance and brutally virile. He takes pleasure in possessing women and having the upper hand,

1. Giving a straightforward definition of femininity that does not adhere to stereotypes is close to impossible. Naturally, feminist criticism has taken great issue with classifications of the kind described here. Nevertheless, these characteristics are among those most typically (and traditionally) associated with ideas of femininity. 
and it is clearly stated that he is an experienced rapist (p. 255) and finds sexual gratification in resistant women: "He liked resistance; he had come to expect it on the Border" (p. 372). Thus the ground is clearly prepared for his behaviour towards Mary, taking her by force and then self-assuredly maintaining that she has enjoyed the act (which she finally acknowledges is correct). This serves to demonstrate the utter feminisation and subjugation of Mary as she is made subject to a male power which strips her of her influence as queen of Scots and paves the way towards her victimization by England at Fotheringay.

Plaidy's portrayal of Elizabeth Tudor and Mary as polar opposites further supports a reading of Mary as the feminine victim, and of Scotland as bullied by England. Elizabeth is shown to be sensible and ambitious whereas Mary is controlled by her emotions and places far too much trust in her nobles. James Stuart, Earl of Moray, Mary's illegitimate halfbrother, recognises this and sees his own success as dependent on this distinction:

She [Mary] was so pretty, and so impetuously foolish at times. She would never be a great ruler; she would be no match for the Queen beyond the Border. Elizabeth of England would never have tolerated in her country such a powerful nobleman as James intended to be in Scotland. (p. 267)

Elizabeth is clearly shown to be working against Mary, employing her powerful network of spies to destabilise Mary's power; for instance, knowing that marrying Darnley will ultimately prove destructive for Mary, Elizabeth pretends to oppose the match while in reality she "exults at the success of her plan to bring disorder into Scotland" (pp. 336-7). Accordingly, Mary is outmatched by Elizabeth, and Plaidy clearly indicates that, given her inadequacies, the historical Mary never stood a chance. Surrounded by treacherous and power-contending lords, beset by the spies of Elizabeth, Catherine de Medici and others, hated by a preacher whose influence over the Scottish people is highly prejudicial to her, manipulated by the ambitious Bothwell, her eventual imprisonment in Scotland seems an inevitable step towards her ultimate fate.

Although sympathetic towards Mary, Plaidy does not clear the Scottish queen of blame in Darnley's murder. The novel clearly implicates her; she wishes "to God someone would rid me of him" (p. 401), marriage with Bothwell is what she desires "beyond all things" (p. 426), and she knows that by bringing Darnley to Kirk-o'-Field she is assisting in the plans for his assassination. Plaidy is clear on her reasons here:

[...] because I have been unable to exonerate her from implication in the murder of Darnley I want to stress that when assessing Mary we must not weigh her deeds and behaviour by present day standards. She lived in an 
age when life was cheap and cruelty part of daily existence. [...] It is very necessary to remember this when considering the part Mary played in luring her husband to the house in Kirk-o'-Field. In her generation she was kinder and more tolerant than most of the people around her; but she herself faced death more than once, and in the sixteenth century, the elimination of human obstacles was not deemed a crime of such magnitude as it is to-day. (Plaidy, Author's Note, 2007, pp. 491-2)

Mary's actions should not be judged from a modern perspective, Plaidy asserts, and Mary's involvement in Darnley's murder is understandable in light of the cultural, political and social climate in which this took place. Importantly, Plaidy's portrayal of Darnley as a foolish, depraved, lecherous, vain, dissolute and cowardly weakling, who is clearly dangerous to Mary's interests as a queen, further downplays Mary's culpability.

Plaidy's sequel to The Royal Road to Fotheringay, The Captive Queen of Scots (1964), deals with Mary's life from her captivity in Scotland and up to her execution at Fotheringay in 1587. Here Mary is portrayed as somewhat matured and disillusioned, yet still prone to let her emotions rule over her better judgement. As expected, Mary's attempts to escape her various places of captivity are central to the action, and as the setting moves to England, Mary's antagonist Elizabeth Tudor becomes ever more important. As before, Mary's feminine, delicate and impulsive nature is emphasised; early in the narrative, Sir Robert Melville sees in her a "certain helplessness [and] certain fragility" that combine with her beauty to make her "completely feminine, possessed of all that was most appealing to men" (p. 26), and later Mary herself reflects that she is "an impulsive woman, governed by her emotions rather than sound common sense" (p. 218). Mary is also often seen by other characters as inadequate to the role of queen because of her frivolousness and her feminine nature. Thus Ruthven reflects that Mary "was meant to be a woman first" and that it "was merely by chance that she was also a Queen" (p. 41), and Sir William Douglas is exasperated at her outburst of joy at receiving fine clothes at Lochleven, thinking it was well "that a Queen who could be so moved by fripperies should be compelled to abdicate" (p. 53). Her womanly beauty, charm and sexual allure are described time and again, and while this serves to uphold the myth of Mary's sensuality and fragile femininity, these repetitive descriptions make for one of the novel's greatest flaws. The same goes for the fact that we are repeatedly invited to sympathise with Mary because of her great kindness, generosity, understanding of other people's distress, and willingness to put her friends' interests before her own. These positive characteristics are so often described in the text (e.g. p. 231, p. 270, p. 274, p. 417) that reading about Mary's generous nature eventually becomes tiresomely repetitive. 
This novel follows its prequel in setting up Mary and Elizabeth as rivals and polar opposites, making it even more clear who the villain is. Elizabeth, as Wallace argues, is presented as "coldly unfeeling, an unnatural and unfeminine figure" (Wallace, 2008, p. 139). While Mary is kind, sympathetic, and far too trusting and guileless, Elizabeth is jealous, double-dealing, wily, petty, unsympathetic towards other people (demonstrated most poignantly in her refusal to allow Scrope to visit his dying wife), spiteful and vindictive. Obviously, the opposition between a feminine, victimized Mary and a vindictive, masculine Elizabeth is yet again highlighted. Significantly, Elizabeth can now determine the fate of a monarch who had before made Scotland seem a threat to England, and also exerts her influence on the Scottish regency so that, in effect, Scotland without Mary has become a docile, willing partner in English policy. Elizabeth is determined to bring down Mary, asks Moray to use "every means at his disposal" to defame Mary (pp. 260-1), and wishes to be rid of Mary, longing "to sever that beautiful head from those graceful shoulders" (p. 354). Her petty, jealous nature is vividly revealed in her decision not to allow Mary to marry any of her suitors: "Mary should have no bridegroom. [...] she could be as celibate as her cousin Elizabeth because this state for them both was the choice of Elizabeth" (p. 261). Although Plaidy clearly overstretches things here, as there is little need to present Elizabeth in such negative and one-dimensional terms in order to gain sympathy for Mary, all the above details drive further home the idea of a victimized Mary and a subjugated Scotland.

It is interesting to compare a much later novel, Philippa Gregory's The Other Queen (2008), with Plaidy's portrayal of a straightforwardly and stereotypically feminine Mary. Gregory's novel deals with the imprisonment of Mary Queen of Scots in England, covering the years 1568 to 1587, or from Mary's flight into England to her execution for plotting against Elizabeth I. The story is told by three narrators; Mary Stuart, Georg Talbot, Earl of Shrewsbury, and Shrewsbury's wife, Bess of Hardwick, thus providing a multiplicity of perspectives on the story of Mary's troubles.

Gregory reveals on her website that The Other Queen was "the culmination of years of research and resistance to the iconic character of Mary Queen of Scots," whom Gregory always felt was "too grand, too beautiful, too doomed, too all round romantic and nonsensical" for it to be worthwhile to take an interest in her. However, after reading John Guy's biography of Mary, Gregory changed her mind and realised that Mary "has been given a reputation that she does not deserve". In her novel Gregory sets out to correct this injustice and attempts to present the Scottish queen in much the same terms as Guy does, as a sympathetic, 
convincing character with many positive attributes and graces alongside some serious flaws. Like Guy's Mary, the Scottish queen is shown to be charming, intelligent, beautiful, witty, generous, brave and daring in her dealings with her enemies, but at the same time impetuous, passionate, stubborn, proud, and too often allowing her emotions to influence her actions. However, Gregory's Mary is nevertheless not an entirely convincing character. Her recurrent reflections on her sacred status as God's anointed queen (e.g. "I am a queen born and bred, a sacred being with inalienable rights", p. 311 ), her overly capricious nature and her repeated willingness to sanction conspiracies that are obviously likely to failclearly jarring with the overall portrayal of Mary being an intelligent woman - all contribute to Gregory's failure to portray Mary realistically. This view is supported by Anna M. Nelson: "This is not her [Gregory's] strongest novel to date: repetitive details clutter the middle of the story, and Mary's voice initially is too much the 'anointed queen' and not quite as human as this reader hoped" (p. 61).

Gregory's self-professed interest in subverting traditional conceptions of Mary is of particular relevance here. She claims that the contrast between the "much married unlucky beautiful Catholic Queen" and "the Protestant triumphant virgin Queen of England" is an oversimplification and "too easy for most historians to resist". Thus she clearly intends to challenge the idea of Mary and Elizabeth as polar opposites. However, George Talbot's reflections on Mary undermine this attempt. These indicate that, due to her very nature, Mary is simply not up to a job that was generally seen as best executed by men, and the previously much-used contrast between Mary and Elizabeth as feminine and masculine opposites is reiterated through Talbot's perspective:

This one [Mary] is quicksilver: she is all fire and light. A queen who wants to hold her lands needs to be more of the earth. A queen who hopes to survive the hatred that all men naturally have for women who contradict God's law and set themselves up as leaders has to be a queen like a rock, a thing of the earth. My own queen is rooted in her power. She is a Tudor with all their mortal appetites and earthly greed. My queen Elizabeth is a most solid being, as earthy as a man. But this is a queen who is all air and angels. She is a queen of fire and smoke. (p. 55)

Outside, male perspectives on Mary and her situation are thus revealing of the novel's exposition of Mary as a female ruler struggling against the efforts of men to control her actions. Indeed, William Cecil's words further underline this view of Mary: "She is an active, energetic fool in the hands of wicked men" (p. 334). Gregory by no means manages to subvert the stereotype; rather, she reinforces it. 
The Other Queen is nevertheless an interesting novel, partly because it emphasises those qualities - or flaws - in Mary that have frequently been used against her. Within this context, Gregory suggests that Mary was indeed justified in acting as she did while under duress in England. Because of her position, the Scottish queen feels that deceitful measures are justifiable; she is a queen and in her view no one has the right to take away her freedom. Fraser emphasises this aspect of Mary's behaviour: "since her imprisonment was illegal, she would consider herself free to try and achieve her liberty by any means in her power". She was a "sovereign princess" over whom Elizabeth had no jurisdiction" (p. 517). By consenting to marry Norfolk, Mary was merely "seeking an honourable exit from her cage approved by Elizabeth" (Fraser, 2002, p. 520). This view is clearly echoed in Gregory's portrayal, which is sympathetic to Mary's hopeless situation. Thus, in the words of Deirdre Donahue, "Gregory makes us grasp Mary's impossible position. She was a queen without a country".

Another positive aspect of Gregory's portrayal is seen in how Mary is ultimately presented as the one who, through her tragic end, will emerge victorious in the history books. As Bess of Hardwick reflects on the day of Mary's execution:

But in a way today, despite them all, the Scots queen has won the battle. $[\ldots]$ she saw in the end that the only way she would defeat Elizabeth [...] was to be the heroine Elizabeth could not be: a tragic heroine, the queen of suffering, cut down in her beauty and her youth. [...] Mary Queen of Scots will be the one that everyone remembers as the beautiful martyr from this reign, whose lovers willingly died for her. Her death is Elizabeth's crime. Her betrayal is Elizabeth's single greatest shame. (p. 435)

Mary Queen of Scots defeats her cousin through her martyrdom; Elizabeth is left with the shame of having agreed to execute her kinswoman. Gregory's message here is clear; it is through her tragic death that Mary has stayed so fixed in the national imagination and been accorded her status as a figure of romance and allure, a symbol of Scotland's victimization by England, and even if many history books do not acknowledge this, Elizabeth was entirely wrong in agreeing to sign Mary's death warrant. Thus the true resonance of Mary's motto, "In My End Is My Beginning," becomes evident. 


\section{Mary on screen}

The critically acclaimed Elizabeth $R$ (BBC, 1971) is comprised of six interconnected plays written by different screenwriters. One of these, "Horrible Conspiracies", focuses on Mary Stuart, the Babington plot and Mary's execution. Played by Vivian Pickles, the Mary of Elizabeth $R$ differs from most other portrayals not only in exhibiting none of the physical beauty and charm belonging to the historical Mary, but also in having little personal allure. Mary is shown as complaining, quarrelsome and naive. She is quick to jump at the chance of escape that Babington's letter seemingly invites, and is ultimately unrepentant. As before, she is presented as very different from Elizabeth, and Ford and Mitchell rightly point out that the separate, juxtaposed scenes that focus alternately on Mary and Elizabeth make clear "the disparities in their personalities" (p. 264). The series is clearly very pro-Elizabeth and since this episode focuses on Elizabeth's fear of mortality, thrown into sharp relief by her dilemma over Mary's execution, Mary's portrayal suffers as a result. However, Mary's assessment of herself to Gifford, a pretended friend who is actually Walsingham's spy, is worthy of some notice:

I regret nothing. I know my faults and my virtues. I know that I am a creature of impulse, seldom thinking before I act, driven on by passions, delighting in the unexpected and bored by sensible caution [...] This is my alchemy, and I rejoice in it. Even though it has brought me much unhappiness, even though it has led me here, I would not have been created differently.

Her own words confirm Mary's status as Elizabeth's impulsive, emotionally driven opposite, and even though this seems rather a contrived method to sum up Mary's character and motives for the viewer, it could work as a convincing piece of dialogue if only the Mary of this series resembled her historical counterpart more and was acted with more spirit.

The film Mary Queen of Scots (1971) differs from Elizabeth R in placing its dramatic focus on Mary herself, although Elizabeth's role is very prominent also. The team behind this film, produced by Hal Wallis and directed by Charles Jarrott, had high expectations for its success, both because of the popularity of historical films in Britain at the time and because of the film's appealing subject matter, the tragic drama of Mary Stuart. However, despite a brilliant cast, with Mary Stuart played by Vanessa Redgrave and Elizabeth Tudor by Glenda Jackson (asked to take on the role due to her success in Elizabeth R), the film was not well received. As has been demonstrated by John Guy and others, it treats historical facts lightly and even distorts them beyond recognition (Guy, 2009; Ford \& Mitchell, 2009, p. 146). Moreover, most contemporary reviewers agreed 
that the film was "little more than an historical soap opera" (Latham, 2011, p. 147). The film's portrayal of Mary Stuart is nevertheless, albeit flawed and sentimentalised, one of interest, not least because it veers away - though only briefly - from merely presenting Mary as the feminine, romanticised icon.

Mary is initially shown as a carefree girl in France, running and laughing with her husband Francois. This "girlish idyll" (Guy, 2009, p. 138) is soon shattered as she is left a widow and transported back to Scotland, an alien and hostile land, and faced with her half-brother James, who clearly intends to rule the country through her. Here, emphasis is already placed on Mary's powerlessness when faced with the complexities and internal rivalries of Scottish politics, yet she shows awareness of her brother's intentions: "Run away and play he tells me, as if I was a child. Davie [Rizzio], I'm trapped [...] He has me in a cage." The impossibility of Mary's position continues to be played out, despite very brief glimpses of Mary effectively holding real power, as when she sends James Stuart into exile because of his resistance to her marriage with Darnley (discussed further below). The film clearly invites us to sympathise with Mary although she is consistently shown to make the wrong choices; from marrying Darnley, taking Bothwell as her lover, getting involved in the plot to murder Darnley and subsequently marrying Bothwell, to riding into England, confident that she will get Elizabeth's help in fighting the Scottish rebels. Her naïve, emotional, impulsive, and feminine characteristics are highlighted, and her love affair with Bothwell is centralised as the driving force behind her actions. Even before they have consummated their relationship, Mary is shown to be deeply affected by the knowledge of his marriage, and is effectively brought into labour at meeting his wife (one of the film's many gross historical inaccuracies). Clearly, this Mary can be read as one who virtually becomes a prisoner of her own choices, as argued by Ford and Mitchell (p. 150). Almost everything she does seems to lead, ultimately, to disaster.

While it is interesting to note that the producer and director of Mary Queen of Scots found inspiration in Antonia Fraser's 1969 best-selling biography of Mary, as well as in Elizabeth $R$ (Ford and Mitchell, 2009, p. 145; Latham, 2011, p. 130; Guy, 2009, p. 149), their portrayal of Mary, especially as played out in her interactions with Elizabeth, is strikingly similar to that of Jean Plaidy in her two-part historical romance series on Mary, discussed above. As in Plaidy's novels, Elizabeth is revealed as the polar opposite of Mary: the shrewd, calculating monarch who puts the interests of state first and does not hesitate to plot against Mary in order to weaken her power in Scotland - and even indirectly sanctions Mary's possible death through her support of the Rizzio plot. The film 
also echoes Plaidy's choice to have Elizabeth place a trap for Mary by offering her Dudley as a husband but in reality wanting her to marry Darnley. Brilliantly played by Jackson (and argued by some to overshadow Redgrave's Mary), ${ }^{2}$ Elizabeth is jealous of Mary's beauty, despises her for her weaknesses and sees her as a threat to herself and English interests. At the same time, she is unwilling to execute Mary because of the principle of divine monarchy. All this is very much in line with Plaidy's portrayal of Elizabeth. What is most strikingly similar to Plaidy's novels, in terms of Mary herself, is Mary's emotional dependence on Bothwell, her utter surrender to him as the one who makes crucial decisions, and her generous, forgiving and optimistic nature, demonstrated most clearly in her willingness to forgive her brother's traitorous behaviour more than once and in her confidence that Elizabeth will help her regain her throne. Considering that the film was made only seven years after Plaidy's novels were published, it is not unlikely that the filmmakers also gained some inspiration from her rendering of Mary Stuart's life.

John Guy argues that in "politics and religion alike, the approach to Mary's personal rule in Scotland in Mary Queen of Scots is strangely schizophrenic" since at one level, "Mary is depicted as a politique and a moderate, at another as a Catholic ideologue" (Guy, 2009, p. 141). This assessment is justified, as seen in the fact that even though Mary expresses a wish to reconcile with her cousin and "sister queen", she frequently refers to Elizabeth as a usurper and heretic. On coming to Scotland, she announces that she will tolerate the new religion while practising her own in private, yet she also makes noises, though privately, about conquering Elizabeth and reinstalling Catholicism in England. As Guy points out, this might be the filmmakers' attempt to reconcile conflicting historical interpretations of Mary, but instead it detracts further from the quality of the film's portrayal. Nevertheless, this does not mean that Mary's character entirely lacks duality or depth here, as is argued by Latham (p. 132). A chief flaw in this film is how sketchy it is in details of Mary's life, as some major events in her career are quickly passed over, some even summed up in a short speech by Elizabeth or other characters. Because of this, we are only given very brief glimpses of Mary as an assertive and powerful monarch, as in during the "Chase-about Raid" where Mary is shown in armour riding at the head of her army after defeating Moray and the rebels. In reality, this was the high point of Mary's career as Queen of Scots, as demonstrated in Guy's biography, and one in which the feminine Mary was entirely replaced by a wholly masculine image: "She sported a pistol in her saddle holster and a steel cap on her head [...] She was at

2. See, for example, Ford and Mitchell, p. 146, and Guy, p. 148. 
ease and in her element. [...] Mary drove the rebels before her without stopping, she retained the initiative from the start" (Guy, 2009, p. 230). In this film, however, such brief glimpses might merely confuse the majority of viewers, whose overriding impression is likely that of an emotional and naïve queen who is unable to rule effectively. And yet, those who have read their history properly are bound to realise that this contributes towards lending some depth and duality to the film's portrayal of Mary. The same can be said of the fact that Mary is shown wearing riding breeches when riding out with Darnley; though brief, this scene pays tribute to the historical Mary's daring assertiveness in wearing breeches underneath her skirts and sitting astride her horse according to Italian custom - a custom that in Scotland was reserved only for men, seen to be improper for a woman and one which caused dismay and suspicion among the Scots (Guy, 2009, p. 80). In her biased discussion of the film, Latham fails to comprehend the full meaning of such scenes, instead interpreting Mary's riding habit as "creating an understated androgyny to match Darnley's effeminate manner" (p. 137). ${ }^{3}$

As in so many fictional and filmic representations of Mary Stuart's story, the relationship and rivalry of Mary and Elizabeth Tudor is central to the film Mary Queen of Scots. In fact, the film's most interesting and powerful scenes are those depicting either Elizabeth talking about Mary or the two occasions on which the two queens meet face to face (a common move in films on Mary, though the two cousins never met in reality). While frequently serving to emphasise Mary's political inadequacies as opposed to Elizabeth's political shrewdness, there are also moments when Mary's spirit and greatness of heart are revealed.

The cousins' differences are most clearly summed up when, discussing Mary with Cecil, Elizabeth argues that Mary will reject Dudley despite being offered the future crown of England and marry Darnley instead, because "that monarch is first a woman". Remonstrating, Cecil replies: "You would not ignore such an offer for a pretty fellow", to which Elizabeth replies: "This woman is first a monarch." Elizabeth's comments encapsulate the myth of Mary and Elizabeth as feminine and masculine opposites, a myth that the film upholds almost from start to finish. Never mind the fact that Elizabeth does exhibit so-called womanly behaviour from time to time, such as a hysterical fit of jealousy when Dudley absentmindedly admits to Mary's charms; the central message is clear nevertheless. Then, when the two queens first meet secretly in Northern England, this

3. This scene is also significant in reflecting Mary's general liking for activities that inverted sexual stereotypes; it is a known fact that she liked cross-dressing and roaming the streets of Edinburgh wearing men's clothes along with her four Maries. See Guy, My Heart is My Own, p. 152. 
opposition of weak and naïve femininity versus strong and shrewd masculinity is the underlying theme of their conversation, which despite this reveals Mary's insight as well as spirited defiance when she retorts:

And you, Madam, who hate me and wish me dead and fear to kill me-you are my mortal enemy. I have noted since the day you denied me a passport through England all the blows you've struck against me. [...] Above all it is clear that Elizabeth fears Mary, and whatever my fate, my son will rule here in time.

Of course, Elizabeth will not admit to fearing Mary, but from her actions throughout it is clear that underneath her scorn there is at least fear of what Mary represents: the Catholic threat. Indeed, her resorting to accuse Mary of being an "infamous royal whore" shows how unsettled she is at Mary's accusation.

In sharp contrast to this scene, the latter scene in which the royal cousins meet is solemn and subdued. Elizabeth tries to convince Mary to beg her forgiveness in writing, in order to save herself from facing trial for involvement in the Babington plot. But Mary is adamant; she has made her peace with God, and intends to die a martyr's death. She is subdued and repentant, implicitly admitting to guilt of the misdeeds attributed to her: "I will deny nothing in this room [...] for I have repented of it all." She knows that she was "greatly punished" through losing her kingdom, her possessions, her son and her husband, and through being imprisoned all this time in "abject misery". Most importantly, she is aware of Elizabeth's greatest fear: "[...] now it is I who pity you, for you cannot avoid ordering the thing you have always feared more than death itself, the judicial murder of an anointed Queen. It will torment you to the end of your days." As Dudley comes for Elizabeth, Mary tells him she will pray for Elizabeth, to which Elizabeth replies: "Madam, if your head had matched your heart I would be the one awaiting death." To indicate that this is an undeserved compliment (Latham, 2011, p. 146) or to say that it "literally sums up the life of $[. .$.$] a monarch who always placed$ her emotions over her intellect, her personal life over her public reputation" (Ford \& Mitchell, 2009, p. 155) is to misunderstand this scene entirely. What Elizabeth's words indicate is simply what she has just realised: that no matter her flaws, Mary has a generous and a brave heart, is gracious to her enemies and courageous in the face of death. Thus, if Mary had been wise to the same extent as she is generous and brave, Elizabeth would never have been able to overcome her. It is in this vein that the film concludes the life of Mary Queen of Scots, despite the airbrushed and romanticized execution, and thus the film is at least in this respect true to the historical Mary. 
Turning to twenty-first century filmic portrayals of Mary, the first episode of the mini series Gunpowder, Treason \& Plot (ITV, 2004) covers Mary's life from her return to Scotland until her surrender to the Scottish lords and subsequent imprisonment in Scotland in 1567. Here, Mary is portrayed - fittingly by the French actress Clémence Poésy - as every inch the Frenchwoman when arriving in Scotland, making her seem all the more unprepared for her new role and alien to her new environment. This is most clearly revealed in her initial inability to deal with matters of state successfully and total reliance on her brother. This Mary fits the historical accounts in that she is beautiful, elegant, graceful, intelligent and witty. Her beauty soon ensnares Bothwell who, differently from historical accounts, falls head over heels in love before Mary thinks of marrying Darnley. From the outset, Bothwell is shown as Mary's opposite, the rough and straightforward Scotsman who speaks broad Scots and is tactless and brutal - and yet strangely charismatic. He is convincingly portrayed as entirely devoted to Scotland and his queen, and, as his relationship with Mary develops, he inspires Mary to come into her own as a Scottish monarch who can fight against and defeat her enemies, demonstrated most clearly in her assertive, and by implication manly, demeanour during the Chase-about Raid. The mini series then takes the view that Mary and Bothwell had an adulterous relationship, finally allowing Mary some sexual fulfilment and adding further sex-appeal fitting the tastes of a modern audience. In addition, Bothwell is made directly responsible for Darnley's murder and Mary's own guilt in this very much debated affair is made clear through her request that Bothwell perform the deed.

Mary's passion for Bothwell, to which she succumbs after considerable resistance, and her decision to have Darnley murdered out of fear for her son, are presented in such terms as to render her entirely sympathetic to a modern audience. In an age when romantic love and sexual fulfilment are valued very highly, Mary's affair with Bothwell seems quite understandable, especially when considering her unhappy marriage to a drunken and abusive husband. A modern audience would moreover sympathise with Mary's choice to have Darnley killed because he is shown to indirectly threaten to harm Prince James unless Mary allows him into her bed again. Motherly love is thus shown to be a determining factor in Mary's actions and overrides all compunction previously demonstrated on her part. Accordingly, the choices made by Mary in Gunpowder, Treason \& Plot are, in modern terms, albeit morally wrong, realistic and understandable ones. Paradoxically, though, these choices and the reasons behind them also serve to once more emphasise a reading of Mary as ruled by her feminine and emotional side instead of by cool, calculated sense. Even in an age when gender stereotypes tend to be repudiated, Mary's feminine 
motives are easily identified with and understood. Moreover, she is shown to be trapped within the constraints of a patriarchal system out of which there is no escape except through these dubious means, whereas a modern woman would be much more easily able to break free, by way of the judicial and social systems.

As in other major portrayals of Mary, Elizabeth Tudor is revealed as Mary's greatest enemy in Gunpowder, Treason $\mathcal{E}$ Plot. As Elizabeth is continually plotting away with Mary's brother Moray, the pair is shown to be at the root of many of the problems that affected Mary's reign in its earlier stages, such as the conflict with the Huntlys, which resulted in the execution of the son of the Earl of Huntly and confiscation of Huntly estates to the Scottish crown. The outcome is dramatic and significant as a curse is laid on Mary by Huntly's wife, who quite naturally grieves sorely for the loss of her son and says to Mary: "may you die in the same manner as my son". The scene is accorded great significance since Lady Huntly's curse is by implication what leads to Mary's cruel fate at Fotheringay Castle. Thereby Elizabeth has a double role in the ultimate execution of her cousin; as a plotter in league with James Stuart she sets in motion a chain of events that eventually bring Mary's death warrant to her desk to be signed. Again, and even more so than in other instances, the Scottish queen is victimized by the English queen; the old Scotland is plotted against and ultimately vanquished by England.

The interpretation of Mary as a feminine victim is echoed in The Virgin Queen (BBC, 2005), in which the dramatic focus remains with Elizabeth and Mary is merely presented as an elusive figure in the background, seldom seen and then very briefly. This very exclusion from our view makes Mary a marginal character and as such seemingly unimportant to Elizabeth and the English court. Yet she stands at the centre of what is a very real threat to Elizabeth: Catholic plots against her life. Ultimately, Mary is clearly portrayed as the victim of English plots, but here it is Walsingham who is instrumental in her downfall by adding an incriminating postscript to Mary's letter to Babington, while Elizabeth's guilt at having Mary executed is vividly demonstrated in Elizabeth's nightmare of finding her own head instead of Mary's placed on the scaffold. Mary's femininity is clearly stated here. There are brief shots of Mary through the door to her room fondling and kissing her lapdog terrier, and brief voiceovers in a strong French accent of a letter from Mary to Elizabeth, where Mary strongly denies ever seeking Elizabeth's death and admonishes Elizabeth for treating her so cruelly. These serve to demonstrate Mary's vulnerable, emotional and - by implication - feminine nature. Significantly, also, the one person able to persuade Elizabeth to order Mary's execution, Robert Dudley, Earl of Leicester, does so through 
outlining Mary's impulsive, feminine nature as opposed to Elizabeth's political astuteness:

You make such a play that as queens you and she are alike. But is it not in how you discharge that duty where the difference lies? She has always let her heart rule her head, put passion before politic need. If you shrink before this duty now, Bess, then indeed you risk the accusation that you are alike. As a woman, you are just not equal to the task.

Thus, in Bethany Latham's words, Leicester shows Elizabeth "the path of feminine weakness" while also appealing to her vanity and pride in "threatening comparison with a woman she considers inferior" (Latham, 2011, p. 233).

Things are different in Shekhar Kapur's film Elizabeth: The Golden Age (2007), where Mary is played by Samantha Morton in a thick Scottish accent (contrary to the historical record). While Mary's presentation is comparable to that of The Virgin Queen, in showing her to be secondary or marginal to the main plot, she is nevertheless more fully developed as a character here as well as endowed with more dramatic influence. In addition, there is no question as to Mary's culpability in the Babington plot, despite her efforts to deny the fact. The Mary of this film is a schemer and a plotter who is obviously and utterly disappointed on hearing that Elizabeth has survived Babington's assassination attempt. She fails to hide her guilt when asking her jailer, Paulet, what all this has to do with her, then collapses to the floor screaming "Traitors!" as she is told that Walsingham has her letters and that she is to be tried for treason. At her trial she places herself above morality and above human law, despite her obvious guilt: "By whose authority do you judge me? God is my only judge."

In her essay on Elizabeth: The Golden Age, Vivienne Westbrook points out how Kapur's film emphasises the contrast between Mary's disappointment at hearing Elizabeth was not killed with "Elizabeth's anguish over signing Mary's death warrant and her subsequent agony at the moment of Mary's execution" (Westbrook, 2009, p. 171). This shows that Kapur wants to stress Elizabeth's reluctance to have Mary executed, along with her fear of her own mortality that is made so evident in the Scottish queen's death. Furthermore, this underlines the historicity of Mary's guilt in the Babington plot, which, after all, is clear from historical evidence. ${ }^{4}$ Even so, it is clear that Mary's disappointment also springs from another source: her desperate desire to break free at last. As Antonia Fraser states

4. See Fraser, Guy and Graham. All three biographies are sympathetic portrayals of Mary, yet all contend that Mary did indicate agreement to the assassination of Elizabeth in her reply to Babington. 
in her biography of Mary: "There can be no doubt but that Mary in her reply [to Babington] took this prospect [the assassination of Elizabeth] briefly into consideration, weighed it against the prospect of her own liberty, and did not gainsay it" (p. 607). Mary's guilt, however, is somewhat downplayed by the fact that in Kapur's film she is shown as merely a pawn in a far-reaching Catholic plot, masterminded by Philip of Spain, to wage a holy war against Elizabeth in order to destroy her and restore Catholicism in England: for an excuse to attack England, Philip needs Elizabeth to execute Mary Stuart. Thus the trap is set not only for Elizabeth but for Mary also, since her proven involvement in the Babington plot is imperative for Elizabeth to sign the death warrant. Interestingly, Westbrook demonstrates how the Catholic threat in Elizabeth: The Golden Age reflects contemporary concerns derived from "the post-9/11 fear of the unseen enemy, the network of infiltrators who are being hosted by the country they hope to ruin" (p. 167). With Catholics being portrayed as the "villains of the piece" (Latham, 2011, p. 165) and as symbolic for the current threat of Islamic fundamentalism, the emphasis on Mary Stuart's guilt is perhaps not a surprising move.

In spite of this, Elizabeth: The Golden Age ultimately presents a romanticized version of Mary's execution, as pointed out by Latham: "she is calm and sensually beautiful, shot in slow motion as she reveals her martyr's red, looks up from the block to forgive the executioner, readies herself for the blow" (Latham, 2011, p. 174). Kapur utilises the visually and emotionally appealing aspects of the historical execution - the red dress, Mary's beauty, her bravery and dignity as she kneels and places her head on the block - but leaves out the shocking, gory bits - the three blows of the axe, Mary's dog running from under her skirt, Mary's severed head rolling onto the floor, leaving only an auburn wig in the executioner's grasp. Considering Mary's previous references to her religion, saying she will die "as a Queen, trusting in the mercy of God", and her dressing in the colour of Catholic martyrdom, the film clearly throws her in the role of a martyr for her religion. In this manner the film can be seen to undermine its own previous presentation of Mary as a callous plotter, somewhat to Elizabeth's disadvantage, as noticed by Westbrook: "Kapur thereby lends a dignified fiction to Mary's departure which curiously undermines Elizabeth while preserving the myth of the divinity of queenship" (p. 172).

Mary Queen of Scots remains a popular icon and a poignant symbol for the subjugation and assimilation of Scotland by England. Regardless of, and perhaps because of, the impossibility to ever know her fully or to get to the heart of the mysteries surrounding her turbulent life, she still fascinates readers and film audiences around the world. Through the centuries, fictional portraits of Mary have kept emphasising her feminine nature. 
The novels and films I have discussed here are no exception. Although these presentations vary in their interpretation of the real historical Mary and the events that shaped her life, she is still very much presented in sharp contrast to the shrewd Elizabeth Tudor, the masculine woman whose political astuteness ultimately serves to bring the feminised, victimised Mary to her tragic destiny.

\section{Bibliography}

Dobson Michael and Watson Nicola J., England's Elizabeth: An Afterlife in Fame and Fantasy, Oxford, Oxford University Press, 2002.

Donahue Deirdre, "Queen of Scots, queen of intrigue", USA Today, 16 September 2008, p. 5d.

Ford Elizabeth A. and Mitchell Deborah G., Royal Portraits in Hollywood: Filming the Lives of Queens, Kentucky, the University Press of Kentucky, 2009.

Fraser Antonia, Mary Queen of Scots, London, Phoenix Press, 2002 [1969]. Giedroyc Coky (ed.), The Virgin Queen, BBC, 2005.

Graham Roderick, An Accidental Tragedy: The Life of Mary, Queen of Scots, Edinburgh, Birlinn, 2008.

Graham Roderick (ed.), Elizabeth R, BBC, 2006 [1971].

Gregory Philippa, "The Other Queen: Historical Background", Philippa Gregory Official Website: <http://www.philippagregory.com/work/ tudor/the-other-queen/the-other-queen-historical-background/20 September 2011>.

—, The Other Queen, London, Harper Collins, 2009 [2008].

GuY John, "Mary Queen of Scots (1971)", in Susan Doran and Thomas S. Freeman (eds), Tudors and Stuarts on Film: Historical Perspectives, Basingstoke-New York, Palgrave Macmillan, 2009, pp. 136-49.

-, My Heart is My Own: The Life of Mary Queen of Scots, London, Harper Perennial, 2004.

Jarrot Charles (ed.), Mary Queen of Scots, Universal Pictures, 1971.

KaPUR Shekhar (ed.), Elizabeth: The Golden Age, Universal Pictures, 2007.

Latham Bethany, Elizabeth I in Film and Television, Jefferson (North Carolina), McFarland \& Company, 2011.

LEwIS Jayne Elizabeth, “Ev'ry Lost Relation': Historical Fictions and Sentimental Incidents in Sophia Lee's The Recess", Eighteenth-Century Fiction, vol. 7, Issue 2, 1995, pp. 165-84.

LewIs Jayne Elizabeth, Mary Queen of Scots: Romance and Nation, London, Routledge, 1998. 
Mackinnon Gillies (ed.), Gunpowder, Treason \& Plot, BBC, 2004.

Nelson Anna M., "The Other Queen”, Library fournal, vol. 133, Issue 12, 1 July 2008, p. 61.

Plaidy Jean, The Captive Queen of Scots, London, Arrow Books, 2007 [1964]. —, Royal Road to Fotheringay, London, Arrow Books, 2007 [1964].

Wallace Diana, The Woman's Historical Novel: British Women Writers, 19002000, Basingstoke and New York, Palgrave Macmillan, 2008 [2005]. Westbrook Vivienne, "Elizabeth: The Golden Age: A Sign of the Times?", in Susan Doran and Thomas S. Freeman (eds), Tudors and Stuarts on Film: Historical Perspectives, Basingstoke-New York, Palgrave Macmillan, 2009, pp. 164-77. 